OPEN ACCESS

Edited by:

Changzhou Yuan,

University of Jinan, China

Reviewed by:

Xihong Lu,

Sun Yat-sen University, China

Xien Liu,

Qingdao University of Science and

Technology, China

*Correspondence:

Jiehua Liu

liujh@hfut.edu.cn

Specialty section:

This article was submitted to

Electrochemistry,

a section of the journal

Frontiers in Chemistry

Received: 10 March 2020 Accepted: 08 April 2020 Published: 26 May 2020

Citation:

Chen P, Zhang K, Tang D, Liu W, Meng F, Huang Q and Liu J (2020) Recent Progress in Electrolytes for

Zn-Air Batteries. Front. Chem. 8:372. doi: 10.3389/fchem.2020.00372

\section{Recent Progress in Electrolytes for Zn-Air Batteries}

\author{
Peng Chen, Keyi Zhang, Dejian Tang, Weilin Liu, Fancheng Meng, Qiuwei Huang and \\ Jiehua Liu*
}

Future Energy Laboratory, School of Materials Science and Engineering, Hefei University of Technology, Hefei, China

Zn-air battery is considered as one of the most promising candidates for next-generation batteries for energy storage due to safety, high energy density, and low cost. There are many challenges in electrolytes for developing high-performance rechargeable $\mathrm{Zn}$-air cells as well as electrocatalysts. An electrolyte is the crucial part of the rechargeable $\mathrm{Zn}$-air batteries that determine their capacity, cycling stability, and lifetime. This paper reviews the most recent progress in designing and fabricating electrolytes in aqueous and flexible $\mathrm{Zn}$-air batteries. The discussion on the surface reaction relationships was covered between air-catalyst-electrolyte and electrolyte-zinc reaction mechanism. We highlight the recent developments of three different electrolytes in zinc-air battery: aqueous electrolyte, room temperature ionic liquid, and quasi-solid flexible electrolyte. Furthermore, the general perspective is proposed for designing and fabricating electrolytes to improve the performance and prolong the lifetime of Zn-air batteries.

Keywords: Zn-air battery, electrolyte, alkaline electrolytes, room temperature ionic liquid, quasi-solid flexible electrolyte

\section{INTRODUCTION}

$\mathrm{Zn}$-air battery has high specific energy $\left(1,218 \mathrm{Wh} \cdot \mathrm{kg}^{-1}\right)$. Meanwhile, its inherent features, including safety and lower cost, make it one of the most promising next-generation batteries (Fu et al., 2017; Tan et al., 2017; Han et al., 2019). The role of electrolytes has been overlooked compared to the hot research on bifunctional air electrodes for $\mathrm{Zn}$-air batteries. The performance of electrolytes directly determines the ionic conductivity and interfacial properties of the $\mathrm{Zn}$-air battery in operation. Furthermore, it further affects the capacity, cycling stability, and charging and discharging efficiency of the cell (Pei et al., 2014). Zn-air batteries are developing toward high efficiency and durability, which cannot separate from the support of electrolyte with excellent performance in all aspects (R. Mainar et al., 2016). Thus, it is urgently significant to delve into the workings of electrolytes in Zn-air batteries (Mainar et al., 2018).

At present, the alkaline electrolyte is still widely used in zinc-based batteries to meet the requirements of low cost and high ionic conductivity and ensure the stability of the zinc electrode (R. Mainar et al., 2016; Xu et al., 2020). However, it is susceptible to environmental $\mathrm{CO}_{2}$ and relative humidity. $\mathrm{Zn}$-air battery is mainly dependent on the performance of the air electrode. Unfortunately, $\mathrm{CO}_{2}$ can lead to the generation of $\mathrm{K}_{2} \mathrm{CO}_{3}$ in the electrolyte, which adversely affects the void in the air electrode (Wang et al., 2014; Fu et al., 2017). Zn-air batteries must solve the problem of evaporation of electrolyte or absorption of water from the external environment to work well in the complex external environment. The former makes the battery expand, and the latter affects the transfer of $\mathrm{OH}^{-}$(Chakkaravarthy et al., 1981; Mainar et al., 2018). Room temperature ionic liquids (RTILs), and solid electrolytes are alternative and effective solutions to solve the above 
problem. However, their performance was limited by their low ionic conductivity and unqualified interface. Therefore, in the following parts, we will discuss the research status of alkaline electrolytes and non-aqueous electrolytes in $\mathrm{Zn}$-air batteries.

\section{AQUEOUS ELECTROLYTE}

$\mathrm{LiOH}, \mathrm{NaOH}$, and $\mathrm{KOH}$ are the common electrolytes for $\mathrm{Zn}-$ air batteries. Compared with neutral and acidic electrolytes, the alkaline electrolytes are well-matched with zinc electrodes and catalyst materials. Meanwhile, there is high ionic conductivity and low viscosity in $\mathrm{KOH}$ electrolyte. When $\mathrm{Zn}$-air battery discharges, the external oxygen enters the battery and reacts (Equation 1) (oxygen reduction reaction) at the gas-liquid-solid interface (oxygen, electrolyte, electrocatalyst). The zinc electrode transports electrons to the air electrode through the external load, and the $\mathrm{OH}^{-}$at the reaction site generates $\mathrm{Zn}(\mathrm{OH})_{4}^{2-}$ (Equation 2). When the concentration of $\mathrm{Zn}(\mathrm{OH})_{4}^{2-}$ reaches the maximum, it will further decompose into $\mathrm{ZnO}$ (Equation 3). The complete reaction of the zinc electrode is shown in Equation 4. During the charging process, backward reaction (Equation 1) (oxygen evolution reaction) is performed at the zinc-electrolyte interface, and electrical energy is stored, while zinc deposits by backward reaction (Equation 3).

$$
\begin{aligned}
\mathrm{O}_{2}+2 \mathrm{H}_{2} \mathrm{O} & +4 \mathrm{e}^{-} \leftrightarrow 4 \mathrm{OH}^{-} \mathrm{E}=0.40 \mathrm{~V} \text { vs. SHE } \\
\mathrm{Zn}+4 \mathrm{OH}^{-} & \leftrightarrow \mathrm{Zn}(\mathrm{OH})_{4}^{2-}+2 \mathrm{e}^{-} \mathrm{E}=1.26 \mathrm{~V} \text { vs. SHE } \\
\mathrm{Zn}(\mathrm{OH})_{4}^{2-} & \leftrightarrow \mathrm{ZnO}+\mathrm{H}_{2} \mathrm{O}+2 \mathrm{OH}^{-} \\
\mathrm{Zn}+2 \mathrm{OH}^{-} & \leftrightarrow \mathrm{ZnO}+\mathrm{H}_{2} \mathrm{O}+2 \mathrm{e}^{-} \mathrm{E}=1.26 \mathrm{~V} \text { vs. SHE }
\end{aligned}
$$

When the concentration of $\mathrm{KOH}$ is $6 \mathrm{M}$, the current exchange density of $\mathrm{Zn} / \mathrm{Zn}^{2+}$ reaches $0.21 \mathrm{~A} \mathrm{~cm}^{-2}$, and the solubility of $\mathrm{ZnO}$ increases with the concentration of $\mathrm{KOH}$ (See and White, 1997; Dyer et al., 2009). Therefore, we must pay attention to the adverse effect of high concentration $\mathrm{KOH}$ electrolyte on the zinc electrode. The high concentration of $\mathrm{ZnO}$ produces excess $\mathrm{Zn}(\mathrm{OH})_{4}^{2-}$ and precipitates after the discharge, which increases the passivation resistance of the zinc electrode. Besides, the oxygen reduction kinetic parameters of zinc were very high, resulting in the dissolution, migration, and redeposition of zinc under various conditions (R. Mainar et al., 2016).

There are two main strategies to solve this problem. One is to change the composition and structure of the zinc electrode, and the other is to find the appropriate electrolyte additives. Reported methods such as making the zinc electrode have a 3-D structure (Parker et al., 2014; Chamoun et al., 2015; Yan et al., 2015) or the efficient additive for the zinc electrode (Fan et al., 2013; Masri and Mohamad, 2013; Huang et al., 2015) have proven to be an effective solution strategy. It is an urgent task to accurately measure the potential and concentration of zinc ions on the surface of the zinc electrode to provide adequate theoretical support for improving the living conditions of the zinc electrode in the alkaline electrolyte. In Table 1, we summarized the recent work on alkaline electrolyte additives. Suitable additives in electrolytes can improve the shape change of the zinc electrode and the performance of the $\mathrm{Zn}$-air battery. If we can reduce the concentration of $\mathrm{KOH}$ as far as possible without affecting the ionic conductivity of the electrolyte, we believe that the performance of the Zn-air battery will be further improved. By adding $\mathrm{K}_{2} \mathrm{CO}_{3}$ to high-concentration $\mathrm{KOH}$ solution and optimize the structure of the battery, Schröder et al. (2015) not only obtained stable electric potential but also improved the actual energy density and long-term stability of the Zn-air battery. Besides, the inhibition of dendrite growth and hydrogen evolution of zinc electrode is also reported in $\mathrm{Zn}$-air battery with the alkaline electrolytes using sodium dodecylbenzene sulfonate (SDBS) (Yang et al., 2004), polyethylene glycol (PEG) (Banik and Akolkar, 2013), tartaric/succinic/citric acid (Lee et al., 2006), and tetra-alkyl ammonium hydroxides (Lan et al., 2007).

$\mathrm{Zn}$-air battery is a semi-open system that requires the rich oxygen from the outer environment to participate in the reaction process. Carbon dioxide $\left(\mathrm{CO}_{2}\right)$ is difficult to avoid in a moist atmosphere. $\mathrm{CO}_{2}$ from the outer atmosphere enters the battery through the air electrode and reacts with $\mathrm{OH}^{-}$in the electrolyte (Equations 5, 6).

$$
\begin{aligned}
\mathrm{CO}_{2}+\mathrm{OH}^{-} & \rightarrow \mathrm{HCO}_{3}^{-} \\
\mathrm{HCO}_{3}^{-}+\mathrm{OH}^{-} & \leftrightarrow \mathrm{CO}_{3}^{2-}+\mathrm{H}_{2} \mathrm{O}
\end{aligned}
$$

The ionic conductivity of the electrolyte becomes weakened due to the generation of $\mathrm{HCO}_{3}^{-}$and $\mathrm{CO}_{3}^{2-}$ and the low solubility of $\mathrm{K}_{2} \mathrm{CO}_{3}$ and $\mathrm{KHCO}_{3}$. When they deposit on the air electrode, the oxygen transfer will be blocked to some extent, resulting in the performance decline of the $\mathrm{Zn}$-air battery. Optimizing the structure of the $\mathrm{Zn}$-air battery and the composition of the gas adsorption layer to allow oxygen to pass through unimpeded but to inhibit the passage of carbon dioxide and water vapor is an ideal solution. To solve the above problems, investigators also put forward several solutions. Pedicini et al. (1996) set up an air manager system for recirculating reactant air in the metalair battery. Goldstein et al. (1997) put forward a scrubber system for removing carbon dioxide from a metal-air or fuel cell battery. Pedicni (2002) proposed to limit carbon dioxide and water vapor when the battery is not in use by loading a responsive air door for an electrochemical cell. There are many solutions to solve these problems, but the limitations are high-cost thresholds and reduced space utilization, which limit the development of $\mathrm{Zn}$-air batteries in practical applications.

The flow electrolyte system is a very effective method for $\mathrm{Zn}$ air batteries. The electrolyte is pumped and circulated through a power system of external pipes and pumps. In addition to removing the precipitated carbonate and other by-products through external filters, the flowing electrolyte improves $\mathrm{OH}^{-}$ transfer and reduces concentration gradients (Iacovangelo and Will, 1985; Cheng et al., 2007). Compared with the static electrolyte, Zn-air battery is much improved including the cycle life and operating voltage with a circulating electrolyte system. However, the power of electrolyte circulation needs to be supported by an external pumping system and electric energy. Therefore, if the electrolyte circulation system is put into practical application, it is necessary to solve the problem that it is difficult to apply to the large-scale grid energy storage system with strict space and weight requirements. 
TABLE 1 | Summary of recently reported alkaline electrolyte additive for Zn-air batteries.

\begin{tabular}{|c|c|c|c|c|c|}
\hline $\begin{array}{l}\text { Electrolyte } \\
\text { composition }\end{array}$ & Electrode materials & $\begin{array}{l}\text { Specific } \\
\text { capacity }\end{array}$ & Power density & Durability & References \\
\hline $\begin{array}{l}6 \mathrm{M} \mathrm{KOH}+0.2 \mathrm{M} \text { zinc } \\
\text { acetate }\end{array}$ & $\begin{array}{l}\text { Zinc plate//Co- } \\
\mathrm{Co}_{3} \mathrm{O}_{4} @ \mathrm{NAC} @ \mathrm{NF}\end{array}$ & $\begin{array}{l}721 \mathrm{mAh} \mathrm{g}_{\mathrm{Zn}}^{-1} \\
@ 10 \mathrm{~mA} \mathrm{~cm}\end{array}$ & $\begin{array}{l}164 \mathrm{~mW} \mathrm{~cm}^{-2} \\
@ 0.63 \mathrm{~V}\end{array}$ & $\begin{array}{l}35 \text { h@10 mA cm }{ }^{-2} \text { for } 20 \text { min } \\
\text { per cycle }\end{array}$ & Zhong et al., 2020 \\
\hline $\begin{array}{l}6 \mathrm{M} \mathrm{KOH}+0.2 \mathrm{M} \text { zinc } \\
\text { acetate }\end{array}$ & Zinc foil// $/ \mathrm{Co}_{3} \mathrm{O}_{4-x} @ \mathrm{CP}$ & $\begin{array}{l}800 \mathrm{mAh} g_{\mathrm{Zn}}^{-1} \\
@ 5 \mathrm{~mA} \mathrm{~cm}\end{array}$ & $\begin{array}{l}122 \mathrm{~mW} \mathrm{~cm}^{-2} \\
@ 230 \mathrm{~mA} \mathrm{~cm}^{-2}\end{array}$ & $\begin{array}{l}150 \text { h@5 mA cm }{ }^{-2} \text { for } 20 \text { min } \\
\text { per cycle }\end{array}$ & Li et al., 2020 \\
\hline $6 \mathrm{M} \mathrm{KOH}+0.2 \mathrm{M} \mathrm{ZnCl}_{2}$ & Zinc plate//Pt-SCFP@CC & $\begin{array}{l}781 \mathrm{mAh} \mathrm{g}_{\mathrm{Zn}}^{-1} \\
@ 10 \mathrm{~mA} \mathrm{~cm}-2\end{array}$ & $\begin{array}{l}122 \mathrm{~mW} \mathrm{~cm}^{-2} \\
@ 214 \mathrm{~mA} \mathrm{~cm}^{-2}\end{array}$ & $\begin{array}{l}80 \text { h@5 } \mathrm{mA} \mathrm{cm}^{-2} \text { for } 20 \text { min per } \\
\text { cycle }\end{array}$ & Wang et al., 2020 \\
\hline $\begin{array}{l}7 \mathrm{M} \mathrm{KOH}+5-20 \% v / \mathrm{v} \\
\mathrm{DMSO}\end{array}$ & Zinc granules//MnO ${ }_{2} @ \mathrm{NF}$ & $\begin{array}{l}550 \mathrm{mAhg}_{\mathrm{Zn}}^{-1} \\
@ 10 \mathrm{~mA} \mathrm{~cm}\end{array}$ & $\begin{array}{l}130 \mathrm{~mW} \mathrm{~cm}^{-2} \\
@ 150 \mathrm{~mA} \mathrm{~cm}^{-2}\end{array}$ & $\begin{array}{l}600 \text { cycles@discharge@75 mA } \\
\text { cm }^{-2} \text { and charge@25 mA cm² }\end{array}$ & Hosseini et al., 2019 \\
\hline $\begin{array}{l}8 \mathrm{M} \mathrm{KOH}+0-50 \% \mathrm{v} / \mathrm{v} \\
\text { ethanol }\end{array}$ & Zinc granules//MnO $\mathrm{Mn}_{2} @ \mathrm{NF}$ & $\begin{array}{l}470 \mathrm{mAh} \mathrm{g} \\
@ 25 \mathrm{~mA} \mathrm{~cm} \\
\text { @ } 25\end{array}$ & $\begin{array}{l}32 \mathrm{~mW} \mathrm{~cm}^{-2} \\
@ 30 \mathrm{~mA} \mathrm{~cm}^{-2}\end{array}$ & $\mathrm{~N} / \mathrm{A}$ & Hosseini et al., 2018 \\
\hline $\begin{array}{l}100 \mathrm{ml} 1 \mathrm{M} \mathrm{KOH}+0.1 \mathrm{~g} \\
\text { water-suspended graphene }\end{array}$ & Zinc strip//Co-Sn-CNP@SS & $\begin{array}{l}212.6 \mathrm{mAh} \mathrm{g}_{\mathrm{Zn}}^{-1} \\
@ 1 \mathrm{~mA} \mathrm{~cm}^{-2}\end{array}$ & $\mathrm{~N} / \mathrm{A}$ & Discharge15 h@1 mA cm-2 & Kumar et al., 2019 \\
\hline
\end{tabular}

NF, Ni foam; CP, carbon paper; CC, carbon cloth; SS, stainless steel.

\section{ROOM TEMPERATURE IONIC LIQUID}

The room temperature ionic liquid is a molten salt that exists as a liquid at or below room temperature. It has a wide electrochemical window and is not easily ignited (Balaish et al., 2014). Therefore, more and more attention was paid to RTILs as substitutes for alkaline electrolytes. The inherent safety and stability of RTILs over a wide range of electrochemical potentials have led to its application in lithium-based batteries (Chou et al., 2008; Xiang et al., 2010). The use of RTILs in Zn-air batteries can effectively solve the problems of zinc electrode damage (Simons et al., 2012), $\mathrm{CO}_{2}$ damage, and electrolyte evaporation (Harting et al., 2012) in the alkaline electrolyte of the water system mentioned above, and make it possible for the battery to work at high temperatures. Moreover, for aprotic RTILs, the absence of protons can effectively avoid the corrosion of the zinc electrode caused by hydrogen evolution. Therefore, RTILs, as an electrolyte for $\mathrm{Zn}$-air batteries, have put on the list in recent years.

RTILs used as an electrolyte for $\mathrm{Zn}$-air cell, zinc oxidize to $\mathrm{Zn}^{2+}$ during discharge, and the reversible electrochemical reaction of zinc in RTILs has proven to be feasible (Xu et al., 2015). What we need to note here is that inappropriate RTILs may form insoluble substances with $\mathrm{Zn}^{2+}$ and make them unable to be reduced effectively. The mechanism of air electrode in RTIL electrolyte was proposed (Kar et al., 2014).

When oxygen reduction occurs in the RTILs electrolyte, oxygen gains electrons and forms a superoxide $\left(\mathrm{O}_{2}^{--}\right)$(Equation 7). This reaction is considered quasi-reversible (AlNashef et al., 2002). For aprotic RTILs, there is no further electron transfer due to the presence of superoxide. In contrast, for protic RTILs, superoxide is a strong nucleophile that can further react with protons in RTILs to form per-hydroxy radical $\left(\mathrm{HO}_{2}^{-}\right)$(Equation 8). Then, per-hydroxy radical can also react with superoxide to form peroxide $\left(\mathrm{HO}_{2}^{-}\right)$(Equations 9,10$)$ and finally complete the reduction process (Equation 11).

$$
\begin{gathered}
\mathrm{O}_{2}+\mathrm{e}^{-} \rightarrow \mathrm{O}_{2}^{--} \\
\mathrm{O}_{2}^{--}+\mathrm{H}^{+} \rightarrow \mathrm{HO}_{2}^{-}
\end{gathered}
$$

$$
\begin{aligned}
& \mathrm{HO}_{2}+\mathrm{O}_{2}^{--} \rightarrow \mathrm{HO}_{2}^{-}+\mathrm{O}_{2} \\
& \mathrm{HO}_{2}^{-}+\mathrm{e}^{-} \rightarrow \mathrm{HO}_{2}^{-} \\
& \mathrm{HO}_{2}^{-}+\mathrm{H}^{+} \rightarrow \mathrm{H}_{2} \mathrm{O}_{2}
\end{aligned}
$$

As for whether hydrogen peroxide can further decompose into $\mathrm{H}_{2} \mathrm{O}$, Zeller (2011) points out that it is determined by the electrode used. According to Kar et al. (2014)'s summary of oxygen reduction and oxygen precipitation reactions in RTILs, in the reaction, as mentioned above, paths have proven to be reversible and relatively stable peroxide products. However, there are still some related disproportionation reactions. Hydrogen peroxide requires less activation energy to produce oxygen, which makes it an effective support for oxygen reduction, and oxygen evolution reactions in RTILs.

The development of RTILs in the Zn-air battery still faces enormous challenges. On the one hand, the high cost of RTILs makes it challenging to use on a large scale. On the other hand, the RTILs' dual-electron reaction mechanism reduces the energy density of the battery, coupled with its high viscosity and low conductivity, which means that the $\mathrm{Zn}$-air battery can only operate at a low current. With $\mathrm{Li}_{0.87} \mathrm{Na}_{0.63} \mathrm{~K}_{0.50} \mathrm{CO}_{3}$ and $\mathrm{NaOH}$ as the electrolyte, Liu et al. (2017) investigated the $\mathrm{Zn}$-air battery able to charge and discharge at $550^{\circ} \mathrm{C}$ for 100 cycles with Coulombic efficiency of 96.9\%. When Ingale et al. (2017) applied diethylmethylammonium trifluoro-methanesulfonate (DEATfO) ionic liquid to the $\mathrm{Zn}$-air battery, they found that although there was no zinc dendrite generation, the weak surface tension of DEATfO resulted in unsatisfactory energy density (Pozo-Gonzalo et al., 2014). Furthermore, Ghazvini et al. (2018) pointed out the positive effect of water addition on ionic interaction when RTIL electrolyte was used in $\mathrm{Zn}$-air batteries. The above work provides a good strategy for improving the performance of the Zn-air battery with RTILs as an electrolyte.

Further, the application of more types of RTILs in Zn-air batteries should be investigated, including the beneficial effects of additives in RTILs. It is also necessary to develop specific bifunctional catalysts to reduce the energy barrier of oxygen reduction reaction and oxygen evolution reaction. Although 
the RTIL electrolyte needs further study in terms of interface properties, the electrochemical reaction mechanism of oxygen and the migration path of active substances, various pieces of evidence indicate that RTILs are the promising electrolytes for Zn-air batteries.

\section{QUASI-SOLID FLEXIBLE ELECTROLYTE}

With the increasing demand for flexible wearable electronic devices, the research on flexible batteries, especially quasi-solid electrolytes, has put forward higher requirements. Compared with other metal-air batteries, $\mathrm{Zn}$-air batteries with high volume energy density have the characteristics of low cost and high safety. In contrast, zinc as an electrode has more energetic mechanical properties and productivity in flexible batteries. For example, $\mathrm{Zn}-\mathrm{MnO}_{2}$ batteries using polymer electrolytes were commercially produced using printing technology (MacKenzie and Ho, 2015). Therefore, it is necessary to carry out scientific research on the structure and performance of a flexible $\mathrm{Zn}$-air battery, and the production of this type of battery and the matching quasi-solid electrolyte needs to be continuously optimized.

The quasi-solid flexible electrolyte is usually prepared from alkaline aqueous solution and polymers such as polyvinyl alcohol (PVA) (Fan et al., 2019), polyacrylic acid (PAA) (Wu et al., 2006; Zhu et al., 2018), gelatin (Park et al., 2015), and related graft copolymer (Yu et al., 2017), which are required to meet the stable configuration, cathode and anode separation, and qualified ionic conductivity. During the preparation process, most of the quasi-solid flexible electrolytes can form a cross-linked network with a large number of hydrophilic functional groups (such as hydroxyl groups), which enables higher water retention and ionic conductivity in quasi-solid flexible electrolytes. In primary $\mathrm{Zn}-$ air cell, alkaline gel electrolyte can effectively reduce the leakage and volatilization of electrolyte and has been applied (Hilder et al., 2009). However, for rechargeable flexible $\mathrm{Zn}$-air batteries, on account of the zinc electrode in the quasi-solid flexible electrolyte, they can only carry a small amount of $\mathrm{Zn}(\mathrm{OH})_{4}^{2-}$.
The process of $\mathrm{ZnO}$ reduction to $\mathrm{Zn}(\mathrm{OH})_{4}^{2-}$ is blocked (Xu et al., 2015). Therefore, it is a big challenge to realize rechargeable $\mathrm{Zn}$-air batteries to work in a large current.

Flexible power density and cycle performance of the $\mathrm{Zn}$-air battery have been highly favored. However, there are several important aspects in the bifunctional catalyst for electrochemical oxygen reactions, the ionic conductivity of the quasi-solid flexible electrolyte, and the performance of the electrolyte-electrode interface. The ionic conductivity of the electrolyte depends mainly on the type of polymer and electrolyte additives. Fan et al. (2019) prepared a porous $\mathrm{PVA}+\mathrm{SiO}_{2}$ electrolyte with high ionic conductivity of $57.3 \mathrm{mS} \mathrm{cm} \mathrm{cm}^{-1}$ and excellent cycling performance and power density. Li et al. (2019) fabricated the polymer dielectric TEAOH-PVA, which still had the ionic conductivity of $30 \mathrm{mS} \mathrm{cm}^{-1}$ after 2 weeks, showing excellent service and working life. It is not difficult to find that a single polymer can hardly become a flexible electrolyte of a quasi-solid state with excellent performance. However, a small number of additives can significantly improve the performance of electrolytes, which is also a process of polymer functionalization. This is mainly because the additive optimizes the structure of the crosslinked network of the polymer electrolyte, increases the number of hydrophilic functional groups (such as hydroxyl groups), and further improves water retention ability of the electrolyte, which has a great influence on the ionic conductivity. Moreover, in addition to the ionic conductivity and water retention performance of the quasi-solid flexible electrolyte, the transfer rate of $\mathrm{OH}^{-}$and $\mathrm{Zn}(\mathrm{OH})_{4}^{2-}$ should also be put to more attention, which has been paid insufficient emphasis at present. Their transfer process also has a profound impact on the energy density and other performance of flexible $\mathrm{Zn}$-air batteries.

There is a challenge to improve the performance of the electrolyte-electrode interface (especially the electrolyte-air electrode interface) in the flexible $\mathrm{Zn}$-air battery. The wettability of the quasi-solid flexible electrolyte was reduced, which makes it much more difficult for the catalyst to perform its function than in the alkaline electrolyte of the water system. When assembling the battery, Xu et al. (2019) pressed the battery for 3 min under

\begin{tabular}{|c|c|c|c|c|c|c|}
\hline $2 \mathrm{D}$ & PAM & Zinc foil//MnO $2 / \mathrm{NRGO} @ \mathrm{CC}$ & 215.6 & N/A & 105 & Miao et al., 2020 \\
\hline $2 \mathrm{D}$ & Porous PVA $+\mathrm{SiO}_{2}$ & Zinc plate// $\mathrm{Co}_{3} \mathrm{O}_{4} @ \mathrm{CC}$ & 57.3 & N/A & 80.9 & Fan et al., 2019 \\
\hline $2 \mathrm{D}$ & PVP & Zinc powder//FeNC-1@Alkaline member & $>10$ & $\mathrm{~N} / \mathrm{A}$ & 250 & Wang et al., 2019 \\
\hline $2 \mathrm{D}$ & PVA & Zinc deposition@Cu film//Ultrathin $\mathrm{Co}_{3} \mathrm{O}_{4} @ \mathrm{CC}$ & N/A & 546 & N/A & Chen et al., 2017 \\
\hline $2 \mathrm{D}$ & PANa-cellulose & Zinc@CNT paper//Fe-N-C@CNTP & $15-28$ & 930 & 210.5 & Ma et al., 2019 \\
\hline 1D & Acrylic polymers & Zinc fiber//NC-Co/CoNx@CF & $\mathrm{N} / \mathrm{A}$ & N/A & 104.0 & Guan et al., 2019 \\
\hline $1 \mathrm{D}$ & PVA@Chiffon band & Zinc wire// $\mathrm{Co}_{3} \mathrm{O}_{4} / \mathrm{N}-\mathrm{rGO} @ \mathrm{CF}$ & 0.33 & 649 & N/A & Li et al., 2018 \\
\hline
\end{tabular}

CC, carbon cloth; SS, stainless steel; CNTP, CNT paper; CF, carbon fiber. 
$3 \mathrm{MPa}$ through a tablet press to make the laminated structure more complete, and the flexible $\mathrm{Zn}$-air battery could stabilize the circulation for $35 \mathrm{~h}$. More exploration is still needed to improve the electrolyte-electrode interface, the preparation of electrolyte, and the battery packaging method.

The flexible $\mathrm{Zn}$-air battery also puts forward to the higher requirements on the bending, stretching, and compression performance of the zinc electrode, air electrode, and electrolyte in the battery. The flexible $\mathrm{Zn}$-air battery is generally divided into the 1D structure (line type) and 2D structure (sandwich shaped). Ma et al. (2019) prepared a dual network hydrogel electrolyte (polyacrylate hydrogel cross-linked by cellulose chains and N,Nmethylene-bisacrylamide anchors) and optimized the structure of the zinc and air electrodes to assemble the $\mathrm{Zn}$-air battery with excellent tensile properties. Pan et al. (2019) constructed a sponge-like squeezable $\mathrm{Zn}$-air battery that performed well after $60 \%$ compression strain or 500 cycles of repeated compression tests. Li et al. (2018) prepared a 1D knittable Zn-air battery with a diameter of only $1.03 \mathrm{~mm}$ through the path, which had an excellent performance of flexibility and charge and discharge.

Table 2 lists more compared performances to provide more meaningful routes for the development of quasi-solid flexible electrolytes for $\mathrm{Zn}$-air batteries. However, it is difficult to get a competent evaluation due to the different battery structure, catalyst, and electrolyte used in recorded works. Therefore, it is necessary to establish a unified evaluation standard for flexible $\mathrm{Zn}$-air battery to evaluate the performance of the corresponding electrolyte better. Furthermore, the composition of the electrolyte in the flexible $\mathrm{Zn}$-air battery is mostly in the "polymer $+\mathrm{KOH}$ solution" mode, which leads to the advantages and disadvantages of the aqueous electrolyte mentioned above acting on the quasisolid electrolyte. At the same time, the combination of RTILs with the polymer may inject new vitality into the safety and stability of $\mathrm{Zn}$-air batteries, but its practical feasibility needs to be verified in the coming future.

\section{SUMMARY}

With the demand for high-power, long life, and flexibility of rechargeable $\mathrm{Zn}$-air batteries, the development of electrolytes

\section{REFERENCES}

AlNashef, I. M., Leonard, M. L., Matthews, M. A., and Weidner, J. W. (2002). Superoxide electrochemistry in an ionic liquid. Ind. Eng. Chem. Res. 41, 4475-4478. doi: 10.1021/ie010787h

Balaish, M., Kraytsberg, A., and Ein-Eli, Y. (2014). A critical review on lithium-air battery electrolytes. Phys. Chem. Chem. Phys. 16, 2801-2822. doi: 10.1039/C3CP54165G

Banik, S. J., and Akolkar, R. (2013). Suppressing dendrite growth during zinc electrodeposition by PEG-200 additive. J. Electrochem. Soc. 160, D519-D523. doi: 10.1149/2.040311jes

Chakkaravarthy, C., Waheed, A. A., and Udupa, H. (1981). Zincair alkaline batteries-a review. J. Power Sources 6, 203-228. doi: 10.1016/0378-7753(81)80027-4

Chamoun, M., Hertzberg, B. J., Gupta, T., Davies, D., Bhadra, S., Van Tassell, B., et al. (2015). Hyper-dendritic nanoporous zinc foam anodes. NPG Asia Mater. 7:e178. doi: 10.1038/am.2015.32 meets the opportunities and challenges. Electrolyte, as a critical part of $\mathrm{Zn}$-air battery, has a profound influence on circulation efficiency, power density, and capacity performance. Up to now, alkaline electrolytes are the mainstream because of their excellent ionic conductivity and interfacial properties. However, alkaline electrolytes are susceptible to the effects of carbon dioxide content and relative humidity in the external environment. On the one hand, the suitable type and proportion of additives should be explored to improve the properties of the alkaline electrolyte. On the other hand, RTILs, as an electrolyte for Znair batteries, have a high threshold of aging, and its protection and safety for zinc electrodes are apparent. Moreover, the research on quasi-solid flexible electrolyte is more conducive to making portable and flexible $\mathrm{Zn}$-air batteries, which provide that the shortcomings in interface performance and ionic conductivity need to be addressed. Finding the right RTILs and polymers makes sense to improve the performance of the electrolyte.

Furthermore, we think that the three electrolytes mentioned above may be integrated with different features. Suitable electrolyte additives can also promote the application of RTILs and quasi-solid electrolytes in $\mathrm{Zn}$-air batteries, and the combination of RTILs and polymers can also improve the performance of electrolytes. The research on electrolytes should be paid more attention to make $\mathrm{Zn}$-air batteries meet the demand for a new generation of energy storage.

\section{AUTHOR CONTRIBUTIONS}

All authors listed have made a substantial, direct and intellectual contribution to the work, and approved it for publication.

\section{FUNDING}

This work was financially supported by the Natural Science Foundation of China (U1832136, 21303038), National Students' Innovation and Entrepreneurship Training Program (201910359010), and Natural Science Foundation of Anhui province (1808085QE140).
Chen, X., Liu, B., Zhong, C., Liu, Z., Liu, J., Ma, L., et al. (2017). Ultrathin $\mathrm{Co}_{3} \mathrm{O}_{4}$ layers with large contact area on carbon fibers as high-performance electrode for flexible zinc-air battery integrated with flexible display. Adv. Energy Mater. 7:1700779. doi: 10.1002/aenm.201700779

Cheng, J., Zhang, L., Yang, Y.-S., Wen, Y.-H., Cao, G.-P., and Wang, X.-D. (2007). Preliminary study of single flow zinc-nickel battery. Electrochem. Commun. 9, 2639-2642. doi: 10.1016/j.elecom.2007.08.016

Chou, S.-L., Wang, J.-Z., Sun, J.-Z., Wexler, D., Forsyth, M., Liu, H.-K., et al. (2008). High capacity, safety, and enhanced cyclability of lithium metal battery using a $\mathrm{V}_{2} \mathrm{O}_{5}$ nanomaterial cathode and room temperature ionic liquid electrolyte. Chem. Mater. 20, 7044-7051. doi: 10.1021/cm80 $1468 \mathrm{q}$

Dyer, C. K., Moseley, P. T., Ogumi, Z., Rand, D. A., and Scrosati, B. (2009). Encyclopedia Of Electrochemical Power Sources. (Newnes: Elsevier Science \& Technology).

Fan, X., Liu, J., Song, Z., Han, X., Deng, Y., Zhong, C., et al. (2019). Porous nanocomposite gel polymer electrolyte with high ionic conductivity and 
superior electrolyte retention capability for long-cycle-life flexible zinc-air batteries. Nano Energy 56, 454-462. doi: 10.1016/j.nanoen.2018.11.057

Fan, X., Yang, Z., Xie, X., Long, W., Wang, R., and Hou, Z. (2013). The electrochemical behaviors of $\mathrm{Zn}$-Al-La-hydrotalcite in $\mathrm{Zn}$-Ni secondary cells. J. Power Sources 241, 404-409. doi: 10.1016/j.jpowsour.2013.04.136

Fu, J., Cano, Z. P., Park, M. G., Yu, A., Fowler, M., and Chen, Z. (2017). Electrically rechargeable zinc-air batteries: progress, challenges, and perspectives. $A d v$. Mater. 29:1604685. doi: 10.1002/adma.201604685

Fu, J., Lee, D. U., Hassan, F. M., Yang, L., Bai, Z., Park, M. G., et al. (2015). Flexible high-energy polymer-electrolyte-based rechargeable zinc-air batteries. Adv. Mater. 27, 5617-5622. doi: 10.1002/adma.201502853

Ghazvini, M. S., Pulletikurthi, G., Cui, T., Kuhl, C., and Endres, F. (2018). Electrodeposition of zinc from 1-ethyl-3-methylimidazolium acetate-water mixtures: investigations on the applicability of the electrolyte for Zn-air batteries. J. Electrochem. Soc. 165:D354. doi: 10.1149/2.0181809jes

Goldstein, J. R., Harats, Y., Sharon, Y., and Naimer, N. (1997). Scrubber system for removing carbon dioxide from a metal-air or fuel cell battery. U.S. Patent No. 5,595,949. (Washington, DC: U.S. Patent and Trademark Office patent application).

Guan, C., Sumboja, A., Zang, W., Qian, Y., Zhang, H., Liu, X., et al. (2019). Decorating $\mathrm{Co} / \mathrm{CoNx}$ nanoparticles in nitrogen-doped carbon nanoarrays for flexible and rechargeable zinc-air batteries. Energy Storage Mater. 16, 243-250. doi: 10.1016/j.ensm.2018.06.001

Han, J., Meng, X., Lu, L., Bian, J., Li, Z., and Sun, C. (2019). Single-atom Fe$\mathrm{Nx}-\mathrm{C}$ as an efficient electrocatalyst for Zinc-Air batteries. Adv. Funct. Mater. 29:1808872. doi: 10.1002/adfm.201808872

Harting, K., Kunz, U., and Turek, T. (2012). Zinc-air batteries: prospects and challenges for future improvement. Z. Phys. Chem. 226, 151-166. doi: 10.1524/zpch.2012.0152

Hilder, M., Winther-Jensen, B., and Clark, N. (2009). Paper-based, printed zinc-air battery. J. Power Sources 194, 1135-1141. doi: 10.1016/j.jpowsour.2009.06.054

Hosseini, S., Abbasi, A., Uginet, L.-O., Haustraete, N., Praserthdam, S., Yonezawa, T., et al. (2019). The influence of dimethyl sulfoxide as electrolyte additive on anodic dissolution of alkaline zinc-air flow battery. Sci. Rep. 9:14958. doi: 10.1038/s41598-019-51412-5

Hosseini, S., Han, S. J., Arponwichanop, A., Yonezawa, T., and Kheawhom, S. (2018). Ethanol as an electrolyte additive for alkaline zinc-air flow batteries. Sci. Rep. 8:11273. doi: 10.1038/s41598-018-29630-0

Huang, J., Yang, Z., Wang, R., Zhang, Z., Feng, Z., and Xie, X. (2015). Zn-Al layered double oxides as high-performance anode materials for zinc-based secondary battery. J. Mater. Chem. A 3, 7429-7436. doi: 10.1039/C5TA00279F

Iacovangelo, C. D., and Will, F. G. (1985). Parametric study of zinc deposition on porous carbon in a flowing electrolyte cell. J. Electrochem. Soc. 132:851.

Ingale, P., Sakthivel, M., and Drillet, J. F. (2017). Test of diethylmethylammonium trifluoromethanesulfonate ionic liquid as electrolyte in electrically rechargeable Zn/air battery. J. Electrochem. Soc. 164, H5224-H5229. doi: 10.1149/2.0351708jes

Kar, M., Simons, T. J., Forsyth, M., and MacFarlane, D. R. (2014). Ionic liquid electrolytes as a platform for rechargeable metal-air batteries: a perspective. Phys. Chem. Chem. Phys. 16, 18658-18674. doi: 10.1039/C4CP02533D

Kumar, K. K., Brindha, R., Nandhini, M., Selvam, M., Saminathan, K., and Sakthipandi, K. (2019). Water-suspended graphene as electrolyte additive in zinc-air alkaline battery system. Ionics 25, 1699-1706. doi: 10.1007/s11581-019-02924-7

Lan, C., Lee, C., and Chin, T. (2007). Tetra-alkyl ammonium hydroxides as inhibitors of $\mathrm{Zn}$ dendrite in $\mathrm{Zn}$-based secondary batteries. Electrochim. Acta 52, 5407-5416. doi: 10.1016/j.electacta.2007.02.063

Lee, C. W., Sathiyanarayanan, K., Eom, S. W., Kim, H. S., and Yun, M. S. (2006). Novel electrochemical behavior of zinc anodes in zinc/air batteries in the presence of additives. J. Power Sources 159, 1474-1477. doi: 10.1016/j.jpowsour.2005.11.074

Li, M., Liu, B., Fan, X., Liu, X., Liu, J., Ding, J., et al. (2019). Longshelf-life polymer electrolyte based on tetraethylammonium hydroxide for flexible zinc-air batteries. ACS Appl. Mater. Interfaces 11, 28909-28917. doi: 10.1021 acsami.9b09086

Li, M., Luo, F., Zhang, Q., Yang, Z., and Xu, Z. (2020). Atomic layer Co3O4$\mathrm{x}$ nanosheets as efficient and stable electrocatalyst for rechargeable zinc-air batteries. J. Catal. 381, 395-401. doi: 10.1016/j.jcat.2019.11.020
Li, Y., Zhong, C., Liu, J., Zeng, X., Qu, S., Han, X., et al. (2018). Atomically thin mesoporous $\mathrm{Co}_{3} \mathrm{O}_{4}$ layers strongly coupled with $\mathrm{N}-\mathrm{rGO}$ nanosheets as high-performance bifunctional catalysts for $1 \mathrm{D}$ knittable zinc-air batteries. $A d v$. Mater. 30, 1703657. doi: 10.1002/adma.201703657

Liu, S., Han, W., Cui, B., Liu, X., Zhao, F., Stuart, J., et al. (2017). A novel rechargeable zinc-air battery with molten salt electrolyte. J. Power Sources 342 , 435-441. doi: 10.1016/j.jpowsour.2016.12.080

Ma, L., Chen, S., Wang, D., Yang, Q., Mo, F., Liang, G., et al. (2019). Super-stretchable zinc-air batteries based on an alkaline-tolerant dual-network hydrogel electrolyte. Adv. Energy Mater. 9:1803046. doi: 10.1002/aenm.201803046

MacKenzie, J. D., and Ho, C. (2015). Perspectives on energy storage for flexible electronic systems. P. IEEE 103, 535-553. doi: 10.1109/JPROC.2015.2406340

Mainar, A. R., Iruin, E., Colmenares, L. C., Kvasha, A., de Meatza, I., Bengoechea, M., et al. (2018). An overview of progress in electrolytes for secondary zinc-air batteries and other storage systems based on zinc. J. Energy Storage 15, 304-328. doi: 10.1016/j.est.2017.12.004

Mainar, R., A., Leonet, O., Bengoechea, M., Boyano, I., de Meatza, I., et al. (2016). Alkaline aqueous electrolytes for secondary zinc-air batteries: an overview. Int. J. Energy Res. 40, 1032-1049. doi: 10.1002/er.3499

Masri, M. N., and Mohamad, A. A. (2013). Effect of adding carbon black to a porous zinc anode in a zinc-air battery. J. Electrochem. Soc. 160, A715-A721. doi: 10.1149/2.007306jes

Miao, H., Chen, B., Li, S., Wu, X., Wang, Q., Zhang, C., et al. (2020). All-solid-state flexible zinc-air battery with polyacrylamide alkaline gel electrolyte. J. Power Sources 450:227653. doi: 10.1016/j.jpowsour.2019.227653

Pan, Z., Yang, J., Zang, W., Kou, Z., Wang, C., Ding, X., et al. (2019). All-solid-state sponge-like squeezable zinc-air battery. Energy Storage Mater. 23, 375-382. doi: 10.1016/j.ensm.2019.04.036

Park, J., Park, M., Nam, G., Lee, J. S., and Cho, J. (2015). All-solidstate cable-type flexible zinc-air battery. Adv. Mater. 27, 1396-1401. doi: 10.1002/adma.201404639

Parker, J. F., Chervin, C. N., Nelson, E. S., Rolison, D. R., and Long, J. W. (2014). Wiring zinc in three dimensions re-writes battery performance-dendrite-free cycling. Energy Environ. Sci. 7, 1117-1124. doi: 10.1039/C3EE43754J

Pedicini, C., Sieminski, D. P., Skeggs, L. T., Young, J. E., and Cherry, E. C. (1996). Air manager system for recirculating reactant air in a metal-air battery. U.S. Patent No. 5,560,999. Washington, DC: U.S. Patent and Trademark Offic patent application.

Pedicni, C. S. (2002). Load responsive air door for an electrochemical cell. U.S. Patent No. 6,350,537. Washington, DC: U.S. Patent and Trademark Office patent application.

Pei, P., Wang, K., and Ma, Z. (2014). Technologies for extending zinc-air battery's cyclelife: a review. Appli. Energy 128, 315-324. doi: 10.1016/j.apenergy.2014.04.095

Pozo-Gonzalo, C., Virgilio, C., Yan, Y., Howlett, P. C., Byrne, N., MacFarlane, D. R., et al. (2014). Enhanced performance of phosphonium based ionic liquids towards 4 electrons oxygen reduction reaction upon addition of a weak proton source. Electrochem. Commun. 38, 24-27. doi: 10.1016/j.elecom.2013.10.004

Schröder, D., Borker, N. N. S., König, M., and Krewer, U. (2015). Performance of zinc air batteries with added $\mathrm{K}_{2} \mathrm{CO}_{3}$ in the alkaline electrolyte. J. Appl. Electrochem. 45, 427-437. doi: 10.1007/s10800-0150817-0

See, D. M., and White, R. E. (1997). Temperature and concentration dependence of the specific conductivity of concentrated solutions of potassium hydroxide. J. Chem. Eng. Data 42, 1266-1268. doi: 10.1021/je97 0140x

Shinde, S. S., Lee, C. H., Jung, J.-Y., Wagh, N. K., Kim, S.-H., Kim, D.-H., et al. (2019). Unveiling dual-linkage 3D hexaiminobenzene metal-organic frameworks towards long-lasting advanced reversible Zn-air batteries. Energy Environ. Sci. 12, 727-738. doi: 10.1039/c8ee02679c

Simons, T., Torriero, A., Howlett, P., Macfarlane, D. R., and Forsyth, M. (2012). High current density, efficient cycling of $\mathrm{Zn}^{2+}$ in 1-ethyl-3-methylimidazolium dicyanamide ionic liquid: The effect of $\mathrm{Zn}^{2+}$ salt and water concentration. Electrochem. Commun. 18, 119-122. doi: 10.1016/j.elecom.2012.02.034

Tan, P., Chen, B., Xu, H., Zhang, H., Cai, W., Ni, M., et al. (2017). Flexible Zn-and Li-air batteries: Recent advances, challenges, and future perspectives. Energy Environ. Sci. 10, 2056-2080. doi: 10.1039/c7ee01913k 
Wang, K., Pei, P., Ma, Z., Xu, H., Li, P., and Wang, X. (2014). Morphology control of zinc regeneration for zinc-air fuel cell and battery. J. Power Sources 271, 65-75. doi: 10.1016/j.jpowsour.2014.07.182

Wang, W., Tang, M., Zheng, Z., and Chen, S. (2019). Alkaline polymer membranebased ultrathin, flexible, and high-performance solid-state Zn-air battery. Adv. Energy Mater. 9, 1803628. doi: 10.1002/aenm.201803628

Wang, X., Sunarso, J., Lu, Q., Zhou, Z., Dai, J., Guan, D., et al. (2020). High-performance platinum-perovskite composite bifunctional oxygen electrocatalyst for rechargeable Zn-air battery. Adv. Energy Mater. 10:1903271. doi: 10.1002/aenm.201903271

Wu, G., Lin, S., and Yang, C. (2006). Alkaline Zn-air and Al-air cells based on novel solid PVA/PAA polymer electrolyte membranes. J. Membr. Sci. 280, 802-808. doi: 10.1016/j.memsci.2006.02.037

Xiang, H., Yin, B., Wang, H., Lin, H., Ge, X., Xie, S., et al. (2010). Improving electrochemical properties of room temperature ionic liquid (RTIL) based electrolyte for Li-ion batteries. Electrochim. Acta 55, 5204-5209. doi: 10.1016/j.electacta.2010.04.041

Xu, L., Liu, J., Chen, P., Wang, Z., Tang, D., Liu, X., et al. (2020). High-power aqueous $\mathrm{Zn}-\mathrm{H} 2 \mathrm{O} 2$ batteries for wide applications. Cell Rep. Phys. Sci. 1:100027. doi: 10.1016/j.xcrp.2020.100027

Xu, M., Ivey, D., Xie, Z., and Qu, W. (2015). Rechargeable Zn-air batteries: Progress in electrolyte development and cell configuration advancement. J. Power Sources 283, 358-371. doi: 10.1016/j.jpowsour.2015.02.114

Xu, N., Zhang, Y., Wang, M., Fan, X., Zhang, T., Peng, L., et al. (2019). High-performing rechargeable/flexible zinc-air batteries by coordinated hierarchical Bi-metallic electrocatalyst and heterostructure anion exchange membrane. Nano Energy 65:104021. doi: 10.1016/j.nanoen.2019.1 04021

Yan, Z., Wang, E., Jiang, L., and Sun, G. (2015). Superior cycling stability and high rate capability of three-dimensional $\mathrm{Zn} / \mathrm{Cu}$ foam electrodes for zinc-based alkaline batteries. RSC Adv. 5, 83781-83787. doi: 10.1039/C5RA16264E
Yang, H., Cao, Y., Ai, X., and Xiao, L. (2004). Improved discharge capacity and suppressed surface passivation of zinc anode in dilute alkaline solution using surfactant additives. J. Power Sources 128, 97-101. doi: 10.1016/j.jpowsour.2003.09.050

Yu, M., Wang, Z., Hou, C., Wang, Z., Liang, C., Zhao, C., et al. (2017) Nitrogen-doped $\mathrm{Co}_{3} \mathrm{O}_{4}$ mesoporous nanowire arrays as an additive-free aircathode for flexible solid-state Zinc-air batteries. Adv. Mater. 29:1602868. doi: 10.1002/adma.201602868

Zeller, R. A. (2011). Effects Of Extrinsic And Intrinsic Proton Activity On The Mechanism Of Oxygen Reduction In Ionic Liquids. (Temp, AZ: Arizona State University, ProQuest Dissertations Publishing).

Zhong, X., Yi, W., Qu, Y., Zhang, L., Bai, H., Zhu, Y., et al. (2020). Co single-atom anchored on $\mathrm{Co} 3 \mathrm{O} 4$ and nitrogen-doped active carbon toward bifunctional catalyst for zinc-air batteries. Appl. Catal., B 260, 118188. doi: 10.1016/j.apcatb.2019.118188

Zhu, L., Zheng, D., Wang, Z., Zheng, X., Fang, P., Zhu, J., et al. (2018). A confinement strategy for stabilizing ZIF-derived bifunctional catalysts as a benchmark cathode of flexible all-solid-state Zinc-air batteries. Adv. Mater. 30:e1805268. doi: 10.1002/adma.201805268

Conflict of Interest: The authors declare that the research was conducted in the absence of any commercial or financial relationships that could be construed as a potential conflict of interest.

Copyright (C) 2020 Chen, Zhang, Tang, Liu, Meng, Huang and Liu. This is an openaccess article distributed under the terms of the Creative Commons Attribution License (CC BY). The use, distribution or reproduction in other forums is permitted, provided the original author(s) and the copyright owner(s) are credited and that the original publication in this journal is cited, in accordance with accepted academic practice. No use, distribution or reproduction is permitted which does not comply with these terms. 